\title{
Logging-debris and vegetation-control treatments influence competitive relationships to limit 15-year productivity of coast Douglas-fir in western Washington and Oregon
}

\author{
Timothy B. Harrington ${ }^{\mathrm{a}, *}$, Robert A. Slesak ${ }^{\mathrm{b}}$, James P. Dollins ${ }^{\mathrm{a}}$, Stephen H. Schoenholtz ${ }^{\mathrm{c}}$, \\ David H. Peter ${ }^{\mathrm{a}}$ \\ ${ }^{a}$ USDA Forest Service, Pacific Northwest Research Station, 3625 93rd Avenue Southwest, Olympia, WA 98512, USA \\ ${ }^{\mathrm{b}}$ Department of Forest Resources, University of Minnesota, 115 Green Hall, 1530 Cleveland Ave N., St. Paul, MN 55108, USA

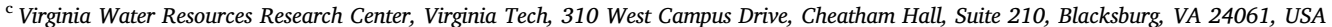

\section{A R T I C L E I N F O}

\section{Keywords:}

Forest productivity

Plantation

Woody debris

Competing vegetation

Debris piles

\begin{abstract}
A B S T R A C T
At two affiliate sites of the North American Long-Term Soil Productivity Study (Matlock, WA and Molalla, OR, USA), soil chemical properties and stand characteristics of planted coast Douglas-fir (Pseudotsuga menziesii var. menziesii) were compared 15 years after forest harvesting and application of three logging-debris configurations (dispersed, piled, or removed) combined with either initial vegetation control (IVC; year 0) or annual vegetation control (AVC; years 0 to 5). At Matlock, soil carbon (C) and nitrogen (N) concentrations each were $17 \%$ greater after IVC than after AVC; at Molalla, soil $\mathrm{N}$ was $13 \%$ greater where debris was removed than where it was dispersed. At Matlock, cover of nonnative Scotch broom (Cytisus scoparius) after IVC was greater where debris was removed $(61 \%)$ than where it was piled $(27 \%)$ or dispersed $(7 \%)$, despite a control treatment in year 4 . Conversely, covers of the native shrubs, trailing blackberry (Rubus ursinus) and salal (Gaultheria shallon) were $20 \%$ to $30 \%$ greater where debris was dispersed than where it was piled or removed. With AVC versus IVC, Douglas-fir stand volume was 34\% to $159 \%$ greater at Matlock depending on the logging-debris treatment, and it was 30\% greater at Molalla independent of debris treatments. However, Douglas-fir survival and growth after AVC did not differ among logging-debris treatments at either site. Survival of Douglas-fir growing $\leq 1 \mathrm{~m}$ from the edge of debris piles at Matlock averaged $16 \%$ greater than that of trees $>1 \mathrm{~m}$ from debris piles. Debris dispersal or piling at Matlock strongly mitigated Scotch broom impacts to forest productivity compared to debris removal. Our findings demonstrate how disturbance characteristics associated with forest harvesting and regeneration practices can influence vegetation recruitment and competitive relationships to place limits on longer-term forest productivity.
\end{abstract}

\section{Introduction}

Limits to temperate forest productivity are typically attributed to soil resource supply, such as soil water and nitrogen availability, which is closely tied to soil texture (Grier et al., 1989). Methods used during forest harvesting and site preparation affect the abundance and species composition of competing vegetation, intensity of soil disturbance, and level of residual organic matter (i.e., logging debris), each of which can interact with soil texture to further modify soil resource supply and alter the development of a regenerating forest stand. Early effects of soil disturbance and organic matter manipulation on the developing forest stand are largely attributable to changes in microclimate (i.e., temperature, vapor pressure deficit, etc.), but after crown closure these effects become increasingly associated with availability of soil resources (Thiffault et al., 2011).

Vegetative competition places limits on available soil resource pools; hence, control of competing vegetation generally increases crop tree growth, and sometimes survival, on a wide variety of forest sites (Powers and Ferrell, 1996; Fleming et al., 2006; Ponder et al., 2012). Absence of a response, or a diminished response, from vegetationcontrol treatments is often attributed to differences in species competitiveness (e.g., native verus non-native species), as well as the inability

Abbreviations: IVC, initial vegetation control (year 0); AVC, annual vegetation control (years 0-5); C, carbon; N, nitrogen; Ca, calcium; K, potassium; Mg, magnesium

${ }^{*}$ Corresponding author.

E-mail address: tim.harrington@usda.gov (T.B. Harrington). 
of the selected treatment to reduce intensity and duration of competition sufficiently to increase resource availability (Dinger and Rose, 2009; Maguire et al., 2009). Competing vegetation responses to disturbance also can confound and shroud differences in forest productivity resulting from factors such as soil compaction and organic matter removal (Powers and Fiddler, 1997).

Logging debris that remains after forest harvesting influences the microenvironment by shading the soil surface and reducing soil temperatures (Devine and Harrington, 2007; Trottier-Picard et al., 2014). Logging debris is also a pool of site nutrients and C, and its removal may cause a concurrent reduction in soil nutrient pools and reduced productivity over time (Powers et al., 1990). A surface cap of debris can delay recovery of understory vegetation, especially ruderal species (Cox and Van Lear, 1985; Hendrickson, 1988; Harrington et al., 2013; Trottier-Picard et al., 2014; Peter and Harrington, 2018), and it can create a mulching effect that conserves soil water (Powers and Fiddler, 1997; O'Connell et al., 2004; Roberts et al., 2005; Harrington et al., 2018).

Recent research on the influence of logging debris on forest communities in the Pacific Northwest has identified both positive and negative changes in plant species abundances. For example, during the first five years after forest harvesting, a heavy debris treatment (20-25 $\mathrm{Mg} \mathrm{ha}^{-1}$ ) inhibited germination and cover development of nonnative Scotch broom (Cytisus scoparius (L.) Link) relative to that in a light debris treatment $\left(10-15 \mathrm{Mg} \mathrm{ha}^{-1}\right)$, while it stimulated cover development of the native species, trailing blackberry (Rubus ursinus Cham. \& Schltdl.) and salal (Gaultheria shallon Pursh) (Harrington and Schoenholtz, 2010; Peter and Harrington, 2018). These vegetation responses could result in long-term changes in species abundances, as well as their competitive influences on forest stand development.

The North American Long-Term Soil Productivity (LTSP) Study was established in 1989 to determine effects of organic matter removal, soil compaction, and vegetation control on development of forest stands (Powers et al., 1989). Tenth-year results of the LTSP Study indicated consistent increases in tree biomass across the study region from vegetation control (Powers et al., 2005; Ponder et al., 2012). In contrast, whole-tree harvesting has not had a consistent negative effect on tree biomass in the LTSP study, although combining it with forest floor removal has resulted in soil and foliar nutrient deficiencies on some sites (Ponder et al., 2012).

At two affiliate LTSP Study sites in the Pacific Northwest, greater accretions of soil $\mathrm{C}$ and $\mathrm{N}$ during the first 10 years after forest harvesting were generally associated with lower intensity treatments of logging debris (i.e., dispersed) and competing vegetation (initial vegetation control (IVC) in year 0) versus higher intensity treatments (Slesak et al., 2011, 2016). However, the observed increases in soil C and $\mathrm{N}$ have not been linked to increased growth of the planted coast Douglasfir (Pseudotsuga menziesii (Mirb.) Franco var. menziesii). Instead, Douglas-fir productivity has depended primarily on how the treatments influenced abundance of the dominant competitors (Harrington and Schoenholtz, 2010). At the Matlock, Washington, USA site, removal or piling of logging debris stimulated greater cover development of Scotch broom from soil-stored seeds than dispersal of debris. Greater cover of Scotch broom after IVC than after annual vegetation control (AVC; years 0-5) resulted in a 30\% reduction in Douglas-fir survival by year 5 and a $180 \%$ reduction in Douglas-fir stand volume by year 10 . At the Molalla, Oregon, USA site, greater cover of trailing blackberry after IVC than after AVC resulted in a $31 \%$ decrease in Douglas-fir stem diameter by year 5 and a $26 \%$ reduction in Douglas-fir stand volume by year 10 . However, at both sites Douglas-fir growth has not differed among logging debris treatments when combined with AVC.

Based on these previous results, in year 15 we expected to see a continuation in the trends for soil chemistry, as well as similar reductions in Douglas-fir stand volume attributable to the early differences in vegetation control. Additionally, we did not expect to see differences in Douglas-fir productivity among debris treatments when combined with
AVC. However, because Scotch broom was controlled in year 4 at Matlock via a directed application of herbicides, we expected the species' recovery and impacts to stand development by year 15 to depend on how the treatments influenced abundance of its competitors, Douglas-fir, trailing blackberry, and salal. Therefore, the objective of this paper is to identify effects of the logging-debris and vegetationcontrol treatments on 15th-year stand characteristics of planted Douglas-fir at Matlock and Molalla. Specifically, we identified treatment effects on forest floor and mineral soil properties and on survival and growth of Douglas-fir. At Matlock, we determined treatment effects on Scotch broom abundance and its competitive relationships with Douglas-fir and trailing blackberry. Lastly, we determined potential neighborhood effects of debris piles on survival and growth of individual Douglas-fir.

\section{Methods}

\subsection{Study sites}

Two study sites were selected that contrasted strongly in soil texture and nutrient pools: Matlock, WA, USA $\left(47.206^{\circ} \mathrm{N}\right.$ latitude, $123.442^{\circ} \mathrm{W}$ longitude) and Molalla, OR, USA $\left(45.196^{\circ} \mathrm{N}\right.$ latitude, $122.285^{\circ} \mathrm{W}$ longitude) (Fig. 1). For example, soils at Matlock and Molalla, respectively, differed strongly in sand content (65\% and 37\%), coarse fragment content ( $68 \%$ and $38 \%$ ), water holding capacity ( 42 and $155 \mathrm{~mm}$ ), total soil $\mathrm{N}\left(3,300\right.$ and $\left.7,220 \mathrm{~kg} \mathrm{ha}^{-1}\right)$, and total soil C (92 and $170 \mathrm{Mg}$ ha $^{-1}$ ) at 0-60 $\mathrm{cm}$ (Slesak et al., 2016). The very gravelly loamy sands of the Grove series at Matlock are classified as sandy-skeletal, mixed, mesic, Dystric Xerorthents formed in glacial outwash averaging $1.5 \mathrm{~m}$ depth (Soil Survey Staff, USDA-NRCS, 2019). The cobbly loams of

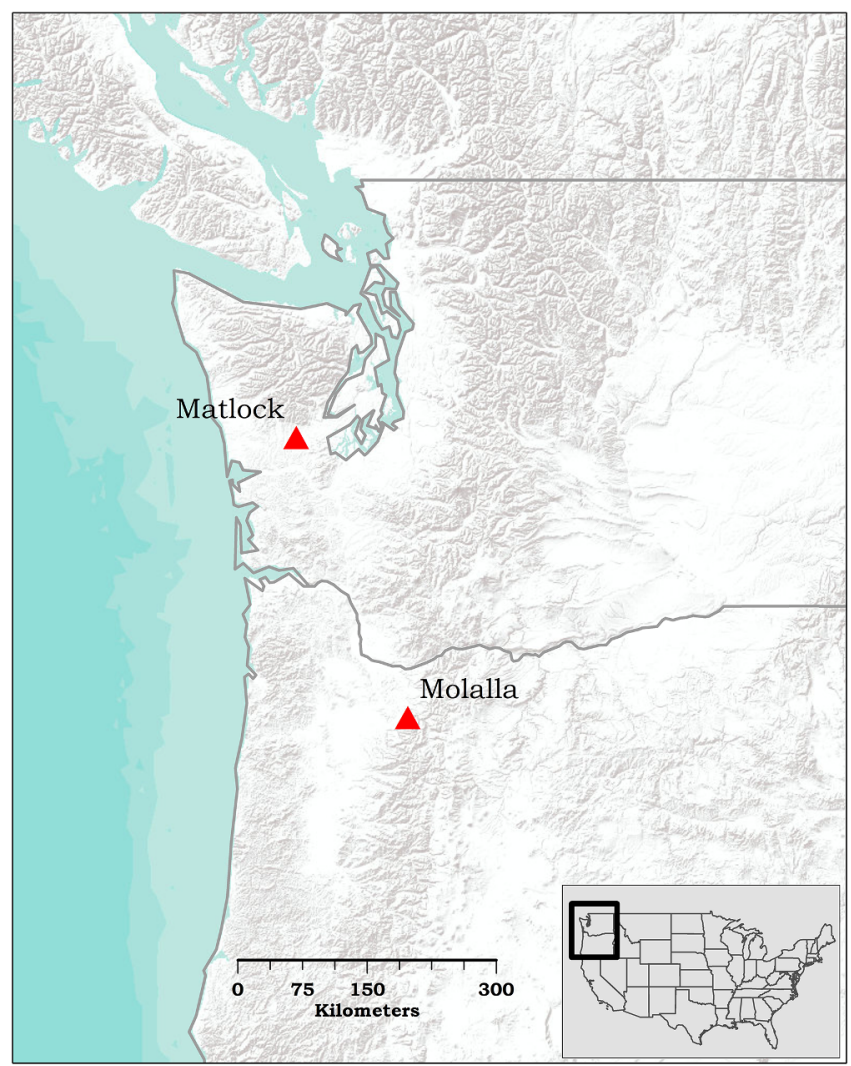

Fig. 1. Approximate locations of the Matlock, WA and Molalla, OR, USA study sites. Sources of map terrain features include Environmental Systems Research Institute (ESRI), U.S. Geological Survey, and U.S. National Oceanic and Atmospheric Administration; sources of USA state boundaries include ESRI, TomTom, U.S. Department of Commerce, and U.S. Census Bureau. 
the Kinney series at Molalla are classified as fine-loamy, isotic, mesic Andic Dystrudepts formed in basic agglomerate residuum with an average soil depth of $1.4 \mathrm{~m}$ (Soil Survey Staff, USDA-NRCS, 2019). The sites are affiliates of the North American LTSP study (Powers et al., 2005). The regional climate is characterized by mild, wet winters and warm, dry summers. Long-term (1981-2010) annual precipitation was estimated to be 243 and $164 \mathrm{~cm}$ for Matlock and Molalla, respectively (PRISM Climate Group, 2019). Matlock and Molalla were estimated to have the same Douglas-fir site index (36 m at 50 years; King, 1966) based on measurements from the pre-harvest stands (Harrington and Schoenholtz, 2010). Potential natural vegetation includes the western hemlock (Tsuga heterophylla (Raf.) Sarg.)/salal plant association at Matlock (Henderson et al., 1989) and the western hemlock/Oregongrape (Mahonia nervosa (Pursh) Nutt.)/swordfern (Polystichum munitum (Kaulf.) Presl) and western hemlock/Oregon grape-salal plant associations at Molalla (Halverson et al., 1986).

\subsection{Experimental design and treatments}

A $3 \times 2$ randomized complete-block, factorial design was installed at each site. The first factor included three logging-debris configurations (i.e., dispersed, piled, or removed), and the second factor included two levels of competing vegetation control (initial control (year 0) or annual control (years 0-5)). Note that some of the previous reports from these studies did not include analysis of the debris-piled treatment because of research funding limitations (e.g., Slesak et al., 2009, 2011, 2016). Each factorial combination was replicated four times as 0.3-ha (50- $\times 60-\mathrm{m})$ treatment plots. Blocking was based on aspect (Molalla only) and proximity to access roads (Matlock and Molalla).

After locating plot corners and assigning treatments, the existing stand of Douglas-fir at each site was clearcut harvested via directional felling with chainsaws during spring 2003. To confine soil disturbance, designated machine trails were marked at 20 -m intervals along the 60 $\mathrm{m}$ dimension of each plot immediately after trees were felled. Machine traffic was confined to the trails during removal of logs and piling or removal of logging debris as specified by treatment. Logs were not skidded but rather transported to the road by tracked loaders (i.e., shovel logging). A tracked excavator with a clamshell bucket was used to pile or remove debris; little or no mineral soil was displaced during these processes. All pre-harvest woody debris was left in place, and debris treatments were completed within 30 days of logging before materials had dried to the point of needle-fall. The dispersed and piled debris configurations removed only merchantable portions of the tree (minimum piece-size diameter $12.7 \mathrm{~cm}$ and length $3.7 \mathrm{~m}$ ), and the debris-removed treatment removed logging debris $>5.1 \mathrm{~cm}$ in diameter in addition to the merchantable portions. Logging debris mass (estimated in summer 2003 via the line transect method; Brown, 1974) was $60 \%$ to $70 \%$ greater in the debris-dispersed treatment (22.5-24.0 $\mathrm{Mg} \mathrm{ha}{ }^{-1}$ ) than in the debris-removed treatment (13.5-13.9 $\mathrm{Mg} \mathrm{ha}^{-1}$ ) (Harrington and Schoenholtz, 2010). The area separating piles in the debris-piled treatment had similar debris mass (13.2-14.1 $\mathrm{Mg} \mathrm{ha}^{-1}$ ) as the debris-removed treatment. Because of the difficulty of non-destructive sampling of debris piles, their combined mass per hectare was assumed to equal the average mass of debris in the dispersed treatment.

All plots received an initial herbicide treatment (initial vegetation control; IVC) in late summer 2003 (i.e., year 0) to temporarily control woody competing vegetation and prevent future overtopping of planted Douglas-fir. In the annual vegetation control (AVC) treatment, assigned plots were treated with herbicides in the fall or spring during years 1 to 5 to temporarily control all competing vegetation (Harrington and Schoenholtz, 2010). Study sites were hand planted with locally adapted, genetically improved $1+1$ bare-root seedlings of coast Douglas-fir in spring 2004 at a 3- x 3-m spacing (i.e., 1,111 trees ha ${ }^{-1}$ ).

\subsection{Forest floor and soil sampling and analysis}

The forest floor and mineral soil were sampled only from the dispersed and removed logging-debris treatments throughout the study period because of research funding limitations. Forest floor materials ( $<0.6 \mathrm{~cm}$ diameter for woody matter) were collected in October 2018 within a square $0.1-\mathrm{m}^{2}$ frame placed at five systematically located points in each plot. Forest floor samples were composited by plot and placed in labeled plastic bags for transport to the laboratory. Mineral soil samples were then collected from the same five points in each plot with a 10-cm diameter bucket auger. Mineral soil samples were collected from three depth increments $(0-15 \mathrm{~cm}, 15-30 \mathrm{~cm}$, and $30-60 \mathrm{~cm}$ ), composited by depth increment and plot, and thoroughly mixed; subsamples for each depth increment were placed in labeled plastic bags for transport to the laboratory. At the laboratory, forest floor samples were dried at $65{ }^{\circ} \mathrm{C}$ to a constant weight, weighed, and then milled to pass a 2-mm mesh using a Thomas Wiley Mill (Thomas Scientific, Model 4 Wiley Mill, Swedesboro, NJ, USA). Mineral soil samples were air-dried and sieved to pass a 2-mm mesh. Forest floor and mineral soil total soil $\mathrm{C}$ and $\mathrm{N}$ were measured by dry combustion using a LECO Dumas combustion technique on a Fisons NA1500 NCS Elemental Analyzer (ThermoQuest Italia, Milan, Italy). Mineral soil exchangeable $\mathrm{Ca}, \mathrm{K}$, and $\mathrm{Mg}$ were extracted with ammonium acetate, and extract concentrations were measured with inductively coupled plasma spectroscopy (Varian Vista MPX, Varian, Palo Alto, CA, USA). All estimates of soil $\mathrm{C}$ and nutrient concentrations are reported on an oven-dry $\left(105{ }^{\circ} \mathrm{C}\right)$ basis. Mineral soil samples were collected and analyzed in the laboratory with the same procedures as above prior to treatment and at 2, 5, and 10 years after study establishment (exception: soil samples for year 2 were not analyzed for cations).

\subsection{Vegetation and debris pile measurements}

Douglas-fir stand development was monitored on a $10 \times 10$ grid of trees (i.e., a 30- $\times 30-\mathrm{m}$ measurement plot) nested within each treatment plot. Stem diameter at breast height (dbh; nearest $\mathrm{mm}$ at $1.3 \mathrm{~m}$ above ground) was measured on each tree per measurement plot at the end of the 2018 growing season, corresponding to 15 years after study establishment. Total height (nearest $\mathrm{dm}$ ) was measured on a randomly selected $30 \%$ sample of trees. Crown height (height to the lowest live branch; nearest $\mathrm{cm}$ ) also was measured on each height measurement tree. To identify potential neighborhood effects of debris piles on survival and growth of Douglas-fir, individual seedlings were coded soon after planting in spring 2004 to indicate those likely to be influenced by debris piles, defined as being located $\leq 1 \mathrm{~m}$ from the edge of a debris pile. Debris piles and associated seedlings were then mapped relative to permanent plot corners so that their approximate locations could be viewed in aerial photographs. Additionally, width (nearest dm measured in north-south and east-west directions) and maximum height (nearest $\mathrm{dm}$ ) of each pile were recorded.

To better understand the competitive relationships associated with Scotch broom that are limiting forest productivity at Matlock, during summer 2018 we visually estimated 15th-year cover (nearest 5\%) of Scotch broom, Douglas-fir, trailing blackberry, and salal within a 7.5-m radius circular subplot ( $0.018 \mathrm{ha}$ ) located at the center of each study plot. These data were combined with previous measurements (Harrington and Schoenholtz, 2010; Slesak et al., 2016) to graphically illustrate cover development of these species.

\subsection{Data analysis}

Except for site comparisons of debris pile density and size, data from each site were analyzed separately in SAS (SAS Institute, Inc., 2013) with a significance level $(\alpha)$ of 0.05 . Preliminary analyses of the mineral soil data indicated that treatment effects and time trends were consistent across soil depths; therefore, we analyzed responses across 
the entire $60-\mathrm{cm}$ depth of sampling. For each mineral soil chemistry variable, a weighted mean was calculated to accurately represent the 0 to $60-\mathrm{cm}$ depth of sampling. Data for each variable were subjected to repeated-measures analysis of variance (ANOVA) in SAS PROC Mixed to test the significance of the fixed factors, logging-debris treatment, vegetation-control treatment, measurement year, and their interactions, after adjusting for random effects of blocks. Pretreatment values for each variable were included as a covariate in each ANOVA when significant $(P \leq 0.05)$. Linear and quadratic effects of time were tested with orthogonal polynomials in each ANOVA for soil C and N. Scatterplots of the residuals against predicted values indicated assumptions of normality were valid for concentrations of mineral soil $\mathrm{C}$ and $\mathrm{N}$, but concentrations of exchangeable nutrient cations (i.e., $\mathrm{Ca}, \mathrm{K}$, and $\mathrm{Mg}$ ) had non-homogenous residual variances, necessitating logarithmic transformations of these variables. A mixed-effects model also was used to assess treatment effects on forest floor variables for year 15 only.

To predict height of Douglas-fir for which only dbh was measured, the following linear equation was fitted to pooled data from each treatment plot with weighted least squares in SAS PROC Reg:

$H=b_{0}+b_{1}(D)$

where $H$ is height (m), $b_{0}$ and $b_{1}$ are regression coefficients to be estimated, and $D$ is $\mathrm{dbh}(\mathrm{cm})$. The reciprocal of $\mathrm{dbh}$ was used to weight the regression and correct for heteroscedasticity. Douglas-fir stand volume $\left(\mathrm{m}^{3} \mathrm{ha}^{-1}\right)$ was estimated for each plot with the equations of Bruce and DeMars (1974). A parabolic volume equation was used to estimate volume of Douglas-fir having a $\mathrm{dbh}<1 \mathrm{~cm}$.

Mean values for 15th-year Douglas-fir survival, dbh, height, crown height, and stand volume were calculated for each plot. Data for each Douglas-fir variable were subjected to ANOVA in SAS PROC Mixed to test the significance of the fixed factors, logging-debris treatment, vegetation-control treatment, and their interaction, after adjusting for random effects of blocks. The same analysis was conducted for 15thyear covers of Douglas-fir, Scotch broom, trailing blackberry, and salal at Matlock. Residuals for each response variable were plotted against predicted values to check for non-homogenous variance. An angular transformation was applied to proportionate values of Douglas-fir survival and cover of dominant species at Matlock, and a logarithmic transformation was applied to the Douglas-fir growth variables to homogenize their residual variances (Sokal and Rohlf, 1981). When an ANOVA $F$ statistic indicated presence of significant treatment effects, multiple comparisons of adjusted means were conducted with Tukey's HSD test to control the Type I error rate (Sokal and Rohlf, 1981). Results are presented as back-transformed, least-squares means from the ANOVA.

Pearson correlation coefficients were calculated in SAS PROC Corr for the cover values to identify potential competitive relationships for each pair of the four dominant species at Matlock for regression analysis. Treatment effects on the relationship of Douglas-fir cover versus Scotch broom cover were tested via SAS PROC Reg using the extra sums-of-squares approach in linear regression (Neter et al., 1989). The full regression model included indicator variables to represent separate intercepts and slopes for each of the six treatments. $F$-tests were applied to compare the full model to reduced models having a common intercept, a common slope, or both. The same approach was used to test treatment effects on the relationship of Scotch broom cover versus trailing blackberry cover. The selected negative exponential model for Scotch broom cover versus trailing blackberry cover was fitted via SAS PROC Nlin.

An ANOVA was conducted in SAS PROC Mixed to determine if spatial density, size, or plot coverage in debris piles differed between Matlock and Molalla. For each site, paired $t$-tests were conducted in SAS PROC Ttest to compare 15th-year mean values of Douglas-fir survival, $\mathrm{dbh}$, height, and stem volume for trees $\leq 1 \mathrm{~m}$ from the edge of debris piles ( $n=8$ plots per site) versus those $>1 \mathrm{~m}$ away. In each debrispiled plot we randomly selected an equal number of trees $>1 \mathrm{~m}$ from the edge of piles to pair with those $\leq 1 \mathrm{~m}$ from piles; 30 paired $t$-tests were conducted for each variable.

\section{Results}

\subsection{Forest-floor and soil properties}

Forest floor mass averaged $15.7 \mathrm{Mg} \mathrm{ha}^{-1} \pm 0.6$ (s.e.) at Matlock and $12.3 \mathrm{Mg} \mathrm{ha}^{-1} \pm 1.1$ at Molalla. At Matlock, forest floor mass and C concentration each differed significantly among logging-debris treatments $(P=0.033$ and 0.027 , respectively; Table S1). Forest floor mass was greater after logging debris was removed than after it was dispersed (17.1 $\mathrm{Mg} \mathrm{ha}^{-1}$ versus $14.4 \mathrm{Mg} \mathrm{ha}{ }^{-1} \pm 0.8$ (s.e.), respectively; Table S2). In contrast, forest floor C concentration was greater where logging debris was dispersed than where it was removed (425 $\mathrm{g} \mathrm{kg}^{-1}$ versus $349 \mathrm{~g} \mathrm{~kg}^{-1} \pm 23$, respectively). There were no other treatment effects on forest floor properties at either site.

Averaged across treatments, mineral soil $\mathrm{C}$ and $\mathrm{N}$ concentrations at $0-60 \mathrm{~cm}$ increased $23 \%$ and $32 \%$ at Matlock and $19 \%$ and $23 \%$ at Molalla, respectively, during the 15 years since study establishment. Mineral soil chemical properties varied according to the main effects of the logging-debris treatments, vegetation-control treatments, and measurement year; treatment-by-year interactions were not significant (Tables S3 and S4). Early post-harvest treatment differences in mineral soil $\mathrm{C}$ and $\mathrm{N}$ concentrations at both sites were maintained throughout the 15-year study period (Fig. 2). For soil C and N, quadratic effects of time were significant at Matlock because of increases that occurred between year 10 and $15(P \leq 0.02)$, but only linear effects were significant at Molalla $(P<0.001)$. There were no differences in soil $\mathrm{C}$ due to the logging-debris treatments at either site (Table $1 ; P \geq 0.105$ ). At Matlock, soil C, N, Ca, and Mg concentrations were greater after initial vegetation control (IVC) than after annual vegetation control (AVC) $(P \leq 0.045)$. Also at Matlock, soil $\mathrm{K}$ and $\mathrm{Mg}$ were greater where debris was dispersed than where it was removed $(P \leq 0.046)$. At Molalla, soil $\mathrm{N}$ was greater where debris was removed than where it was dispersed $(P=0.038)$. Additionally, soil $\mathrm{K}$ at Molalla was greater after IVC than after AVC $(P=0.003)$.

\subsection{Abundance of dominant species at Matlock}

Cover of each of the dominant species in year 15 differed according to the main effects of the logging-debris treatments (Table S5). Douglasfir cover in the debris-removed treatment (45\%) was substantially lower than in either the debris-dispersed $(63 \%)$ or debris-piled treatments (62\%), but differences were not statistically significant based on multiple comparisons ( $P \geq 0.053$; Fig. 3). Both salal and trailing blackberry had more cover in the dispersed treatment than in the removed or piled treatments. Scotch broom cover differed between IVC and AVC only in the debris-removed treatment (Fig. 4). With IVC, Scotch broom cover averaged $61 \%$ in debris-removed plots; whereas, it averaged $7 \%$ and $27 \%$ in the debris-dispersed and debris-piled treatments, respectively. Covers of Douglas-fir and salal were greater with AVC than with IVC (Fig. 5).

The relationship between Douglas-fir cover and Scotch broom cover at Matlock was best described by a linear model with separate intercepts for IVC and AVC (Fig. $6 ; R^{2}=0.72$ ). Logging-debris treatment did not significantly influence the regression. Independent of Scotch broom cover, Douglas-fir cover averaged $16.5 \%$ greater with AVC than with IVC. The regression slope (0.644) indicated a 6.4\% decrease in Douglasfir cover for every $10 \%$ increase in Scotch broom cover. The regression intercept (65.4) indicated that Douglas-fir cover in the absence of Scotch broom cover averaged $65 \%$ with IVC; whereas, it averaged $82 \%$ (i.e., $65.4 \%+16.5 \%$ ) with AVC.

Scotch broom cover was more strongly correlated with trailing blackberry cover $(r=-0.66, P<0.001)$ than with salal cover $(r=-0.52, P=0.01)$; therefore, we focused the regression analysis on 


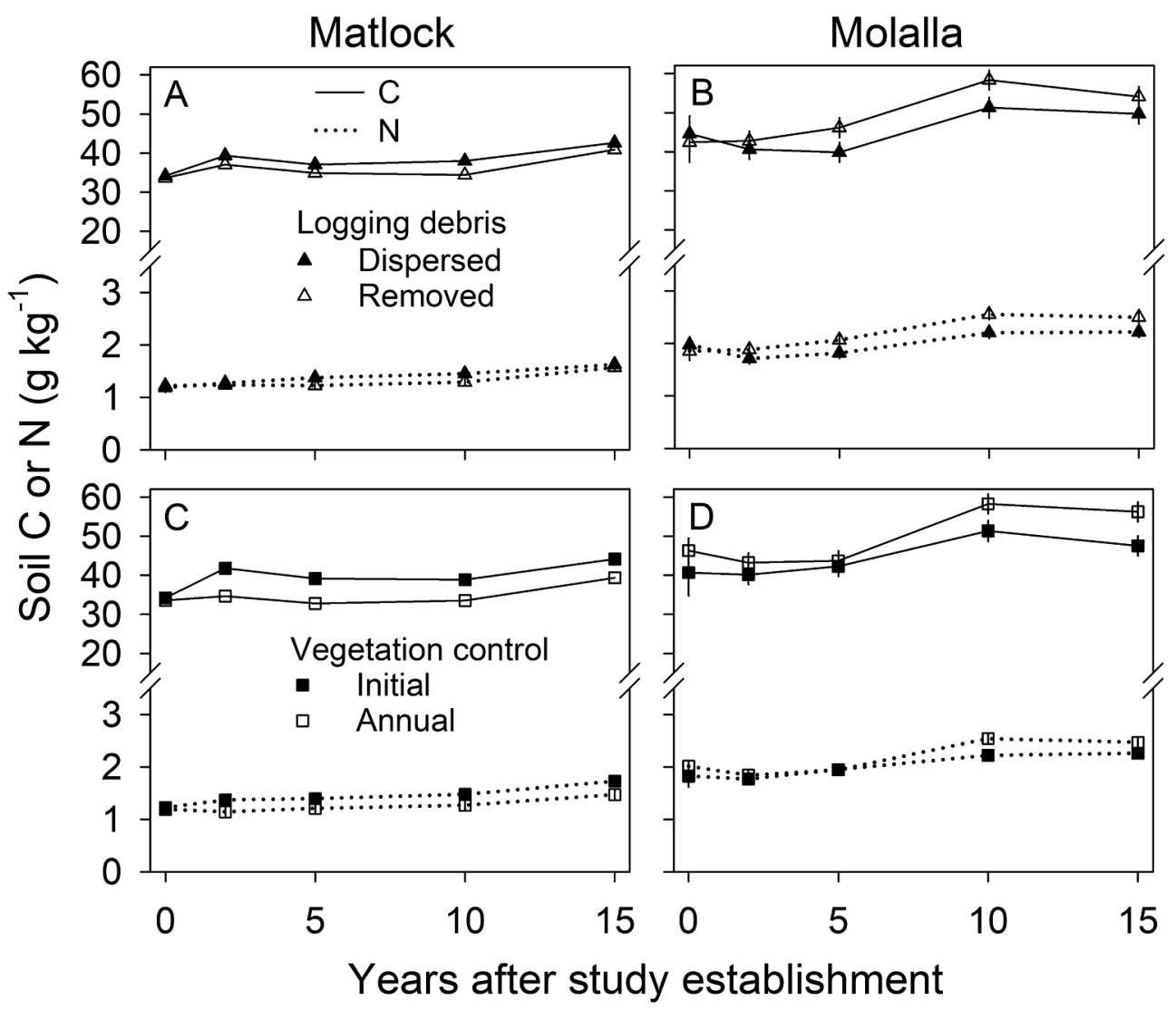

Fig. 2. Mean concentrations of carbon (C) and nitrogen $(\mathrm{N})$ in the top $60 \mathrm{~cm}$ of mineral soil ( \pm standard error) 0 to 15 years after study establishment at Matlock, WA, USA (graphs A and C, respectively) and Molalla, OR, USA (graphs B and D, respectively). Main effects of the vegetation-control treatment were significant at Matlock for $\mathrm{C}$ and $\mathrm{N}$, and main effects of the logging-debris treatment were significant at Molalla for N; see Tables S3 and S4 for ANOVA results.
Table 1

Mean concentrations of mineral soil carbon and nutrients (standard errors below in parentheses) in response to the main effects of the logging-debris and vegetation-control treatments during 15 years after study establishment at the Matlock, WA and Molalla, OR, USA sites.

\begin{tabular}{|c|c|c|c|c|c|}
\hline \multirow[b]{2}{*}{ Site } & \multirow[b]{2}{*}{ Variable $^{\mathrm{a}}$} & \multicolumn{2}{|c|}{ Logging debris } & \multicolumn{2}{|c|}{ Vegetation control } \\
\hline & & Dispersed & Removed & Initial & Annual \\
\hline \multirow[t]{5}{*}{ Matlock } & $\mathrm{C}\left(\mathrm{g} \mathrm{kg}^{-1}\right)$ & $\begin{array}{l}39.3 \mathrm{a} \\
(2.1)\end{array}$ & $\begin{array}{l}36.8 \mathrm{a} \\
(2.1)\end{array}$ & $\begin{array}{l}41.0 \mathrm{~A}^{\mathrm{b}} \\
(2.1)\end{array}$ & $\begin{array}{l}\text { 35.1 B } \\
(2.1)\end{array}$ \\
\hline & $\mathrm{N}\left(\mathrm{g} \mathrm{kg}^{-1}\right)$ & $\begin{array}{l}1.43 \mathrm{a} \\
(0.06)\end{array}$ & $\begin{array}{l}1.33 \mathrm{a} \\
(0.06)\end{array}$ & $\begin{array}{l}1.49 \mathrm{~A} \\
(0.06)\end{array}$ & $\begin{array}{l}1.27 \mathrm{~B} \\
(0.06)\end{array}$ \\
\hline & $\mathrm{Ca}\left(\mathrm{mg} \mathrm{kg}^{-1}\right)$ & $\begin{array}{l}184 \mathrm{a} \\
(14)\end{array}$ & $\begin{array}{l}158 \mathrm{a} \\
(12)\end{array}$ & $\begin{array}{l}197 \mathrm{~A} \\
(15)\end{array}$ & $\begin{array}{l}148 \text { B } \\
(11)\end{array}$ \\
\hline & $\mathrm{K}\left(\mathrm{mg} \mathrm{kg}^{-1}\right)$ & $\begin{array}{l}39.6 \mathrm{a} \\
(1.6)\end{array}$ & $\begin{array}{l}35.1 \text { b } \\
(1.4)\end{array}$ & $\begin{array}{l}38.9 \mathrm{~A} \\
(1.6)\end{array}$ & $\begin{array}{l}35.7 \mathrm{~A} \\
(1.5)\end{array}$ \\
\hline & $\mathrm{Mg}\left(\mathrm{mg} \mathrm{kg}^{-1}\right)$ & $\begin{array}{l}26.1 \text { a } \\
(2.1)\end{array}$ & $\begin{array}{l}22.6 \mathrm{~b} \\
(1.8)\end{array}$ & $\begin{array}{l}28.1 \mathrm{~A} \\
(2.2)\end{array}$ & $\begin{array}{l}21.0 \text { B } \\
(1.7)\end{array}$ \\
\hline \multirow[t]{5}{*}{ Molalla } & $\mathrm{C}\left(\mathrm{g} \mathrm{kg}^{-1}\right)$ & $\begin{array}{l}45.4 \mathrm{a} \\
(2.0)\end{array}$ & $\begin{array}{l}50.3 \mathrm{a} \\
(1.9)\end{array}$ & $\begin{array}{l}45.3 \mathrm{~A} \\
(2.0)\end{array}$ & $\begin{array}{l}50.4 \mathrm{~A} \\
(2.0)\end{array}$ \\
\hline & $\mathrm{N}\left(\mathrm{g} \mathrm{kg}^{-1}\right)$ & $\begin{array}{l}1.99 \mathrm{~b} \\
(0.07)\end{array}$ & $\begin{array}{l}2.25 \text { a } \\
(0.07)\end{array}$ & $\begin{array}{l}2.05 \mathrm{~A} \\
(0.07)\end{array}$ & $\begin{array}{l}2.20 \mathrm{~A} \\
(0.07)\end{array}$ \\
\hline & $\mathrm{Ca}\left(\mathrm{mg} \mathrm{kg}^{-1}\right)$ & $\begin{array}{l}1015 \mathrm{a} \\
(66)\end{array}$ & $\begin{array}{l}945 \mathrm{a} \\
(61)\end{array}$ & $\begin{array}{l}1043 \mathrm{~A} \\
(72)\end{array}$ & $\begin{array}{l}920 \mathrm{~A} \\
(63)\end{array}$ \\
\hline & $\mathrm{K}\left(\mathrm{mg} \mathrm{kg}^{-1}\right)$ & $\begin{array}{l}283 \mathrm{a} \\
(14)\end{array}$ & $\begin{array}{l}276 \mathrm{a} \\
(14)\end{array}$ & $\begin{array}{l}323 \mathbf{A} \\
(16)\end{array}$ & $\begin{array}{l}242 \text { B } \\
(12)\end{array}$ \\
\hline & $\mathrm{Mg}\left(\mathrm{mg} \mathrm{kg}^{-1}\right)$ & $\begin{array}{l}188 \mathrm{a} \\
(13)\end{array}$ & $\begin{array}{l}160 \mathrm{a} \\
(11)\end{array}$ & $\begin{array}{l}184 \mathrm{~A} \\
(14)\end{array}$ & $\begin{array}{l}163 \mathrm{~A} \\
(12)\end{array}$ \\
\hline
\end{tabular}

${ }^{\text {a }}$ For each variable, means followed by the same letter (i.e., lower- and upper-case letters for the logging-debris and vegetation-control treatments, respectively) do not differ significantly $(P>0.05)$.

$\mathrm{b}$ Bold text indicates significant differences.

trailing blackberry. The relationship between Scotch broom cover and trailing blackberry cover was best described by a negative exponential model (Fig. $6 ; R^{2}=0.45$ ). The logging-debris and vegetation-control treatments did not significantly influence the regression. Model predictions indicated that Scotch broom cover decreased from 66\% to $30 \%$ as trailing blackberry cover increased from $10 \%$ to $40 \%$; whereas, it decreased from $30 \%$ to $11 \%$ as blackberry cover increased from $40 \%$ to $80 \%$.

\subsection{Douglas-fir tree and stand characteristics}

The logging-debris treatments influenced Douglas-fir tree and stand characteristics at Matlock but not at Molalla (Table S6). At Matlock, Douglas-fir crown height was slightly greater where debris was piled than where it was dispersed or removed (Table 2). Douglas-fir survival at Matlock varied according to the main effects of vegetation control, and it averaged $16 \%$ greater with AVC than with IVC. At Molalla, Douglas-fir dbh, height, and stand volume were $11 \%, 6 \%$, and $30 \%$ greater, respectively, with AVC than with IVC.

At Matlock, the interaction of the logging-debris and vegetationcontrol treatments was significant for Douglas-fir dbh, height, and stand volume (Table 3). Two key findings from Matlock are associated with this treatment interaction: (1) with AVC, the Douglas-fir growth variables did not differ among logging-debris configurations, and (2) in the debris-piled treatment, the Douglas-fir growth variables did not differ between IVC and AVC.

\subsection{Debris-pile neighborhood effects on Douglas-fir}

Spatial density of debris piles was $75 \%$ greater at Matlock (105 piles $\left.\mathrm{ha}^{-1}\right)$ than at Molalla $\left(60\right.$ piles ha $\left.{ }^{-1}\right)(P=0.002)$. Mean width of piles was greater at Molalla $(3.5 \mathrm{~m})$ than at Matlock $(3.0 \mathrm{~m})(P=0.003)$. Mean height of piles also was greater at Molalla $(1.1 \mathrm{~m})$ than at Matlock $(1.0 \mathrm{~m})(P=0.039)$. However, the areal coverage in piles was greater at Matlock $(7.2 \%)$ than at Molalla $(5.8 \%)(P=0.026)$.

Within-plot sample sizes for the paired $t$-tests of debris-pile neighborhood effects averaged 12 and 8 trees at Matlock and Molalla, 


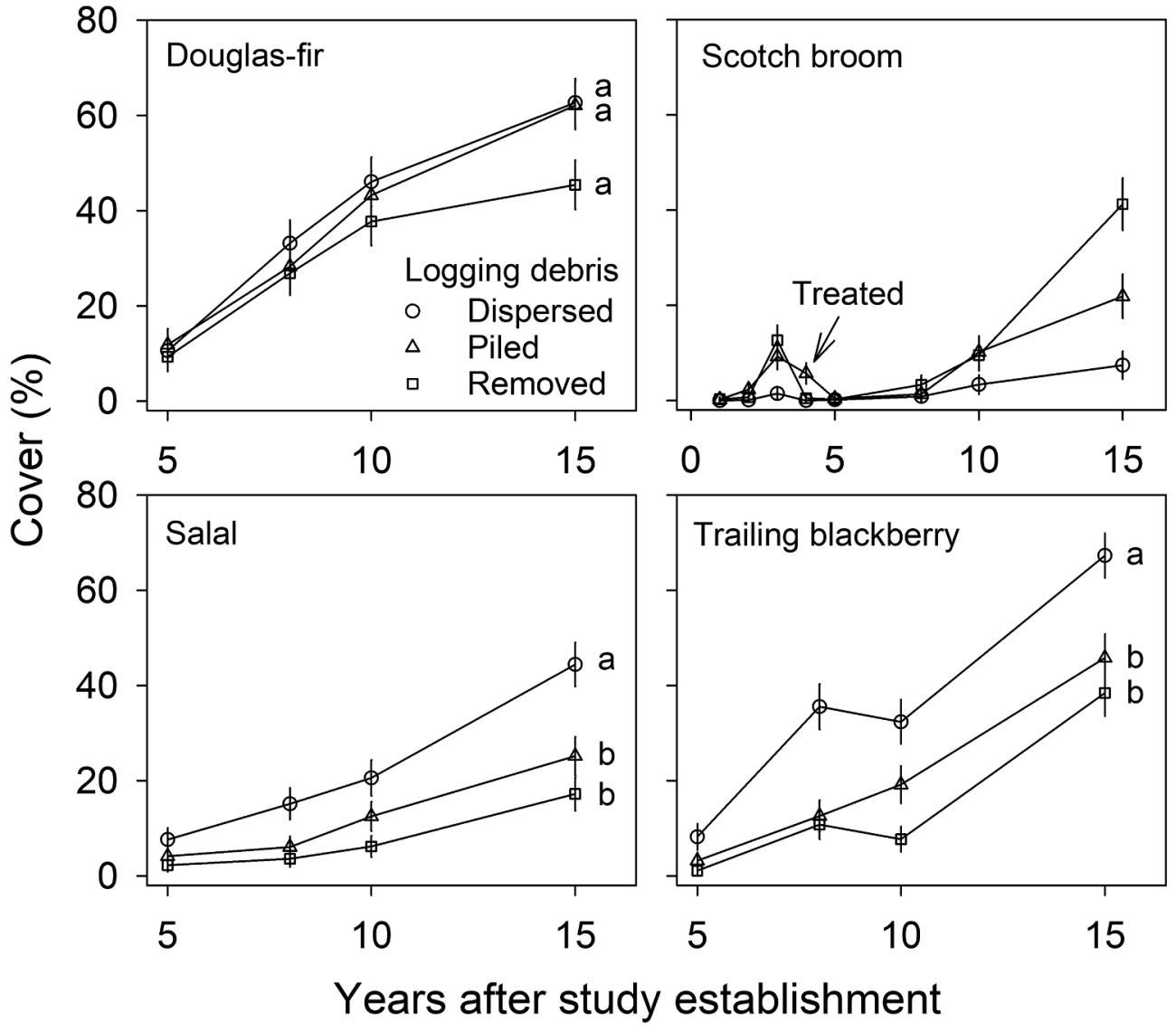

Fig. 3. Mean cover of Douglas-fir, Scotch broom, salal, and trailing blackberry ( \pm standard error) in response to the main effects of the logging-debris treatments at the Matlock, WA, USA site during 5 to 15 years after study establishment. For each species, 15th-year means followed by the same letter do not differ significantly $(P>0.05)$. Arrow indicates fourth year (i.e., 2007) timing of an herbicide treatment to control Scotch broom. See Fig. 4 for comparisons of Scotch broom cover in response to the interaction of the loggingdebris and vegetation-control treatments.

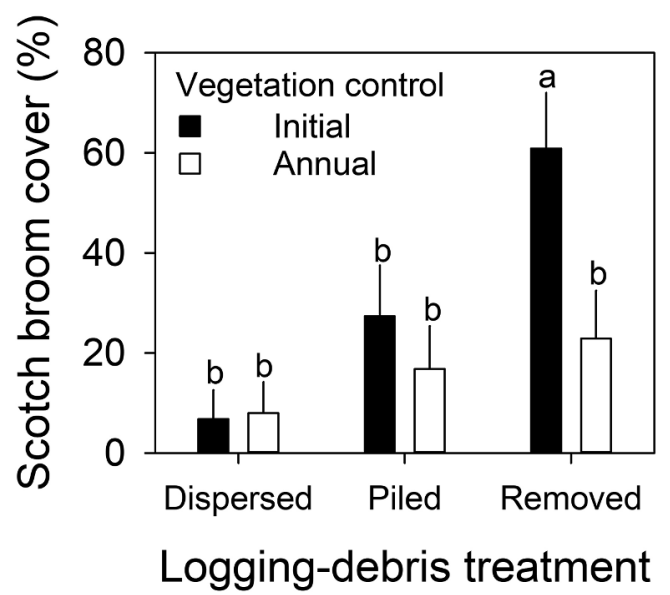

Fig. 4. Fifteenth year mean cover of Scotch broom (with standard error bars) in response to the interaction of the logging-debris and vegetation-control treatments at the Matlock, WA, USA site. Histograms labeled with the same letter do not differ significantly $(P>0.05)$.

respectively, out of a total of 100 trees per measurement plot. At Matlock, survival was $16 \%$ greater (average $P$ from 30 paired $t$ tests $=0.036$ ) for trees growing $\leq 1 \mathrm{~m}$ from the edge of debris piles than for trees growing $>1 \mathrm{~m}$ from piles. At Molalla, pile neighborhood effects were not significant for Douglas-fir survival (average $P=0.448)$. None of the Douglas-fir growth variables from Matlock or Molalla had a significant paired $t$-test for pile neighborhood effects (average $P \geq 0.157$ ).

Plot-level aerial photographs from 0,10 , and 15 years after study establishment provided additional evidence that Douglas-fir growing $\leq 1 \mathrm{~m}$ from the edge of debris piles had a higher survival rate than trees $>1 \mathrm{~m}$ from debris piles (Fig. 7). Neighborhood effects of debris piles on Douglas-fir survival were visually apparent (i.e., surviving trees were clustered around piles). Rapid recovery of Scotch broom following the fourth-year control treatment can be seen by the contrasting change in its cover from year 10 to 15 .

\section{Discussion}

\subsection{Forest-floor and soil properties}

The limited effects of the logging-debris treatments on forest-floor properties indicated that immediate differences in woody debris inputs associated with treatment have largely dissipated by year 15 . One of the few significant effects detected was greater forest floor mass where logging debris was removed than where it was dispersed at Matlock. In that case, it is possible that greater coverage of Scotch broom where logging debris was removed (Fig. 3) resulted in greater inputs to the forest floor (Caldwell, 2006). Overall, forest floor mass increased up to fourfold between year 10 (Matlock: $3.6 \mathrm{Mg} \mathrm{ha}^{-1}$; Molalla: 7.8 $\mathrm{Mg} \mathrm{ha}^{-1}$ ) and year 15 (Matlock: $15.7 \mathrm{Mg} \mathrm{ha}^{-1}$; Molalla: $12.3 \mathrm{Mg}^{-1}$ ), coinciding with the onset of Douglas-fir crown closure and an increase in crown height (i.e., upward crown recession from death of lower branches) (Slesak et al., 2016).

Responses of soil $\mathrm{C}$ and $\mathrm{N}$ concentrations at $0-60 \mathrm{~cm}$ to the loggingdebris and vegetation-control treatments at Matlock and Molalla varied little from what was reported in years 5 and 10 (Slesak et al., 2011, 2016). General patterns of response at Matlock indicated higher $C$ and $\mathrm{N}$ with dispersed logging debris and IVC; whereas, the opposite response was observed at Molalla where soil $\mathrm{C}$ and $\mathrm{N}$ were higher with logging debris removal and AVC. Some exceptions to this general pattern occurred at Molalla, where: (1) greater soil N in AVC versus IVC in year 10 (Slesak et al., 2016) was not detected with the 0 - to 15-year time series, and (2) soil $\mathrm{N}$ was greater with debris removal than with 


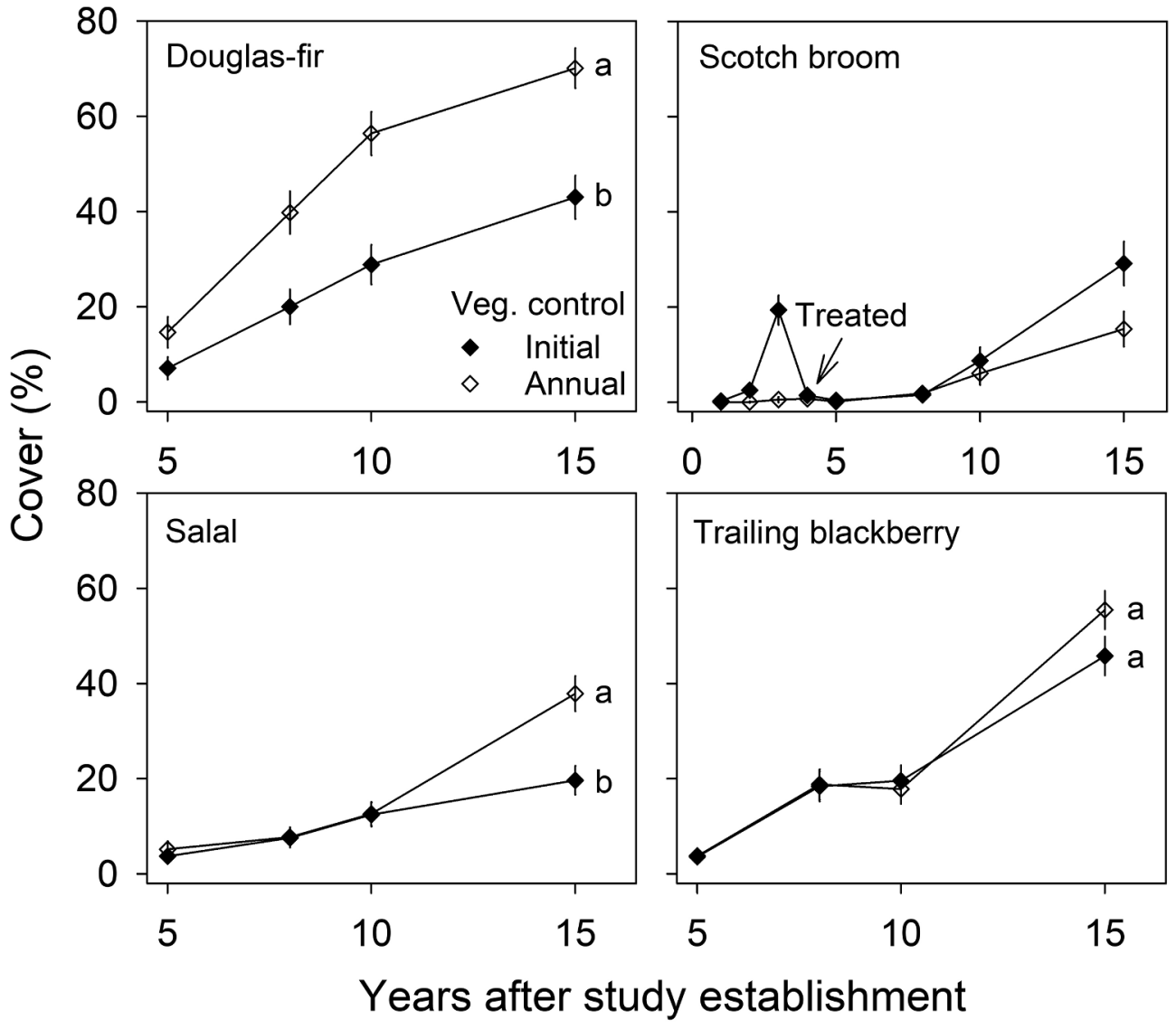

Fig. 5. Mean cover of Douglas-fir, Scotch broom, salal, and trailing blackberry ( \pm standard error) in response to the main effects of the vegetation-control treatments at the Matlock, WA, USA site during 5 to 15 years after study establishment. For each species, 15th-year means followed by the same letter do not differ significantly $(P>0.05)$. Arrow indicates fourth year (i.e., 2007) timing of an herbicide treatment to control Scotch broom. See Fig. 4 for comparisons of Scotch broom cover in response to the interaction of the loggingdebris and vegetation-control treatments. debris dispersal - a difference that was not significant in year 10. These results are likely due to the different analytical approaches used for the 10-year report (i.e., analysis of post-treatment change in soil chemical concentrations; Slesak et al., 2016) compared to this report (i.e., repeated-measures analysis of absolute concentrations), as differences between treatments were relatively consistent from year 5 to 15 (Fig. 2). Similar to our results, Littke et al. (2020) found greater $\mathrm{NH}_{4}^{+}$$\mathrm{N}$ at $5 \mathrm{~cm}$ depth in year 14 at Molalla with debris removal versus dispersal.

Consistent and contrasting responses to treatments between sites could be related to a number of factors, including differences in aboveground biomass (Devine et al., 2011) and its influence on nutrient uptake and $\mathrm{C}$ fixation, or soil properties (i.e., texture, initial $\mathrm{C}$ and $\mathrm{N}$ pools; Slesak et al., 2016) and their influence on C and N efflux and stability. Despite these differences between sites and treatments, in all instances $\mathrm{C}$ and $\mathrm{N}$ concentrations at $0-60 \mathrm{~cm}$ were higher in year 15 than prior to treatment, which aligns with 10-year results from the North American LTSP study and is generally attributed to increased inputs from root decomposition (Powers et al., 2005).

The increase in mineral soil Mg with debris dispersal at Matlock was observed in previous reports (Slesak et al., 2011, 2016) and is likely associated with greater inputs via decomposition of retained debris. The increase in K we observed was also detected by Littke et al. (2020) in year 14, and the mechanism driving the increase is likely the same as for Mg. The positive effects of IVC on mineral soil $\mathrm{C}, \mathrm{N}, \mathrm{Ca}$, and $\mathrm{Mg}$ concentrations at Matlock is likely caused by greater retention of $\mathrm{C}$ and nutrient pools (e.g., less post harvest leaching; Slesak et al., 2009), and at least in the case of $\mathrm{C}$ and $\mathrm{N}$, higher fixation associated with Scotch broom. Likewise, the quadratic time trend in soil $\mathrm{C}$ and $\mathrm{N}$ detected at Matlock due to increases from year 10 to 15 (Fig. 2), when Scotch broom recovery after the fourth-year control treatment was fully underway (Fig. 3), was likely associated with greater abundance of Scotch broom in plots with debris removal and IVC (Fig. 4). Similarly, in year
14 at Matlock, Littke et al. (2020) observed greater soil $\mathrm{NO}_{3}{ }^{-}-\mathrm{N}$ at $5 \mathrm{~cm}$ depth with debris removal versus dispersal and with IVC versus AVC patterns consistent with the abundance of Scotch broom across treatments. Scotch broom is a nitrogen-fixing species known to increase soil C and N pools (Haubensack and Parker, 2004; Caldwell, 2006), especially for high-density populations (Broadbent et al., 2017). Although these positive effects on soil properties may prove beneficial to longterm soil productivity (Powers et al., 1990), they are clearly offset in the short term by the negative effect of Scotch broom competition on Douglas-fir survival and growth (Fig. 6).

\subsection{Abundance of dominant species at Matlock}

Scotch broom cover at Matlock was greatest where debris was removed and IVC was applied; Scotch broom cover in all other treatment combinations did not differ statistically (Fig. 4). Despite repeated attempts to control Scotch broom with herbicides (Harrington and Schoenholtz, 2010), its cover rebounded with the same ranking among logging-debris treatments as seen prior to the fourth-year control treatment (Fig. 3). Because most of the fine debris has now decomposed, variation in abundance of Scotch broom is no longer attributable to shading or smothering effects of logging debris but rather to changes in the plant community that have occurred in the 15 years since study establishment. Greater covers of trailing blackberry and salal in the dispersed treatment than in the piled or removed treatments (Fig. 3) provide evidence of a plant community shift that was able to prevent or slow development of Scotch broom seedlings. Additionally, the opposing responses of salal and Scotch broom to AVC versus IVC (Fig. 5) provide further support for a plant community shift that disfavored recruitment of Scotch broom, because all herbicide treatments were completed by year 5 , and little or no chemical activity would have been present in the 10 years since that time. Salal, a shade-tolerant shrub, is responding positively to increasing Douglas-fir cover, while Scotch 

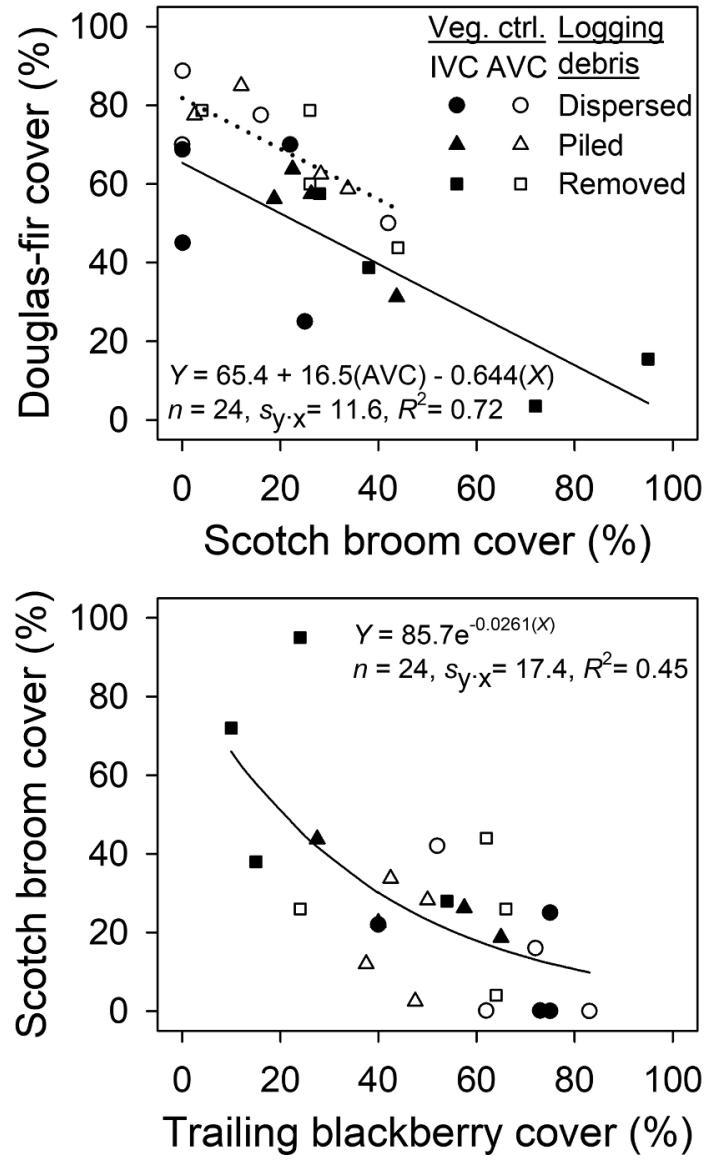

Fig. 6. Crown cover regression relationships for Douglas-fir versus Scotch broom (upper graph) and Scotch broom versus trailing blackberry (lower graph) at the Matlock, WA, USA site 15 years after study establishment. For the regression equation in the upper graph, AVC $=1$ for annual vegetation control (years 0 to 5 ) and AVC $=0$ for initial vegetation control (IVC; year 0 ).

Table 2

Fifteenth year mean tree and stand characteristics of Douglas-fir (standard errors below in parentheses) in response to the main effects of the logging-debris and vegetation-control treatments at the Matlock, WA and Molalla, OR, USA sites.

\begin{tabular}{|c|c|c|c|c|c|c|}
\hline \multirow[b]{2}{*}{ Site } & \multirow[b]{2}{*}{ Variable $^{\mathrm{a}}$} & \multicolumn{3}{|c|}{ Logging debris } & \multicolumn{2}{|c|}{ Vegetation control } \\
\hline & & $\begin{array}{l}\text { Disperse- } \\
\text { d }\end{array}$ & Piled & $\begin{array}{l}\text { Remove- } \\
\text { d }\end{array}$ & Initial & Annua \\
\hline \multirow[t]{2}{*}{ Matlock } & Survival (\%) & $\begin{array}{l}69.0 \mathrm{a} \\
(5.3)\end{array}$ & $\begin{array}{l}71.3 \mathrm{a} \\
(5.1)\end{array}$ & $\begin{array}{l}59.7 \mathrm{a} \\
(6.1)\end{array}$ & $\begin{array}{l}\mathbf{5 8 . 5} \mathbf{B}^{\mathrm{b}} \\
(5.5)\end{array}$ & $\begin{array}{l}74.6 \mathrm{~A} \\
(4.3)\end{array}$ \\
\hline & Crown height (m) & $\begin{array}{l}0.43 \text { ab } \\
(0.02)\end{array}$ & $\begin{array}{l}\mathbf{0 . 4 8} \text { a } \\
(0.02)\end{array}$ & $\begin{array}{l}\mathbf{0 . 4 1} \mathbf{b} \\
(0.02)\end{array}$ & $\begin{array}{l}0.43 \mathrm{~A} \\
(0.02)\end{array}$ & $\begin{array}{l}0.45 \mathrm{~A} \\
(0.02)\end{array}$ \\
\hline \multirow[t]{5}{*}{ Molalla } & Survival (\%) & $\begin{array}{l}90.6 \mathrm{a} \\
(2.8)\end{array}$ & $\begin{array}{l}88.8 \mathrm{a} \\
(3.1)\end{array}$ & $\begin{array}{l}83.6 \mathrm{a} \\
(3.7)\end{array}$ & $\begin{array}{l}87.8 \mathrm{~A} \\
(3.0)\end{array}$ & $\begin{array}{l}87.8 \mathrm{~A} \\
(3.0)\end{array}$ \\
\hline & $\mathrm{DBH}(\mathrm{cm})$ & $\begin{array}{l}14.1 \mathrm{a} \\
(0.48)\end{array}$ & $\begin{array}{l}13.7 \mathrm{a} \\
(0.47)\end{array}$ & $\begin{array}{l}13.6 \mathrm{a} \\
(0.46)\end{array}$ & $\begin{array}{l}\text { 13.1 B } \\
(0.41)\end{array}$ & $\begin{array}{l}\text { 14.6 A } \\
(0.46)\end{array}$ \\
\hline & Height (m) & $\begin{array}{l}10.9 \mathrm{a} \\
(0.35)\end{array}$ & $\begin{array}{l}11.1 \mathrm{a} \\
(0.36)\end{array}$ & $\begin{array}{l}11.0 \mathrm{a} \\
(0.35)\end{array}$ & $\begin{array}{l}\text { 10.7 B } \\
(0.32)\end{array}$ & $\begin{array}{l}\text { 11.3 A } \\
(0.34)\end{array}$ \\
\hline & Crown height (m) & $\begin{array}{l}1.13 \mathrm{a} \\
(0.17)\end{array}$ & $\begin{array}{l}1.24 \mathrm{a} \\
(0.19)\end{array}$ & $\begin{array}{l}1.22 \mathrm{a} \\
(0.19)\end{array}$ & $\begin{array}{l}1.23 \mathrm{~A} \\
(0.17)\end{array}$ & $\begin{array}{l}1.16 \mathrm{~A} \\
(0.16)\end{array}$ \\
\hline & Stand volume $\left(\mathrm{m}^{3} \mathrm{ha}^{-1}\right)$ & $\begin{array}{l}76.7 \mathrm{a} \\
(9.2)\end{array}$ & $\begin{array}{l}70.7 \mathrm{a} \\
(8.5)\end{array}$ & $\begin{array}{l}64.0 \mathrm{a} \\
(7.7)\end{array}$ & $\begin{array}{l}61.7 \mathrm{~B} \\
(6.9)\end{array}$ & $\begin{array}{l}80.2 \mathrm{~A} \\
(9.0)\end{array}$ \\
\hline
\end{tabular}

${ }^{\text {a }}$ For each variable, means followed by the same letter (i.e., lower- and upper-case letters for the logging-debris and vegetation-control treatments, respectively) do not differ significantly $(P>0.05)$.

$\mathrm{b}$ Bold text indicates significant differences.
Table 3

Fifteenth year mean tree and stand characteristics of Douglas-fir (standard errors below in parentheses) in response to the interaction of the logging-debris and vegetation-control treatments at the Matlock, WA, USA site.

\begin{tabular}{|c|c|c|c|c|c|c|}
\hline \multirow[b]{4}{*}{ Variable $^{\mathrm{a}}$} & \multicolumn{6}{|c|}{ Logging-debris } \\
\hline & \multicolumn{2}{|c|}{ Dispersed } & \multicolumn{2}{|l|}{ Piled } & \multicolumn{2}{|c|}{ Removed } \\
\hline & \multicolumn{6}{|c|}{ Vegetation control } \\
\hline & Initial & Annual & Initial & Annual & Initial & Annual \\
\hline $\mathrm{DBH}(\mathrm{cm})$ & $\begin{array}{l}9.9 \mathrm{~b} \\
(0.27)\end{array}$ & $\begin{array}{l}12.8 \mathrm{a} \\
(0.35)\end{array}$ & $\begin{array}{l}11.8 \mathrm{a} \\
(0.32)\end{array}$ & $\begin{array}{l}11.8 \mathrm{a} \\
(0.32)\end{array}$ & $\begin{array}{l}10.0 \mathrm{~b} \\
(0.27)\end{array}$ & $\begin{array}{l}11.8 \mathrm{a} \\
(0.32)\end{array}$ \\
\hline Height (m) & $\begin{array}{l}6.8 \mathrm{~cd} \\
(0.26)\end{array}$ & $\begin{array}{l}9.0 \mathrm{a} \\
(0.35)\end{array}$ & $\begin{array}{l}7.6 \mathrm{bc} \\
(0.30)\end{array}$ & $\begin{array}{l}8.0 \mathrm{ab} \\
(0.31)\end{array}$ & $\begin{array}{l}6.3 \mathrm{~d} \\
(0.25)\end{array}$ & $\begin{array}{l}8.0 \mathrm{ab} \\
(0.31)\end{array}$ \\
\hline Stand volume $\left(\mathrm{m}^{3} \mathrm{ha}^{-1}\right)$ & $\begin{array}{l}22.0 \mathrm{bc} \\
(3.1)\end{array}$ & $\begin{array}{l}42.9 \mathrm{a} \\
(6.0)\end{array}$ & $\begin{array}{l}29.3 \mathrm{ab} \\
(4.1)\end{array}$ & $\begin{array}{l}39.3 \mathrm{a} \\
(5.5)\end{array}$ & $\begin{array}{l}13.8 \mathrm{c} \\
(1.9)\end{array}$ & $\begin{array}{l}35.8 \mathrm{ab} \\
(5.0)\end{array}$ \\
\hline
\end{tabular}

${ }^{\text {a }}$ For each variable, means followed by the same letter do not differ significantly $(P>0.05)$.

broom, a shade-intolerant shrub, is responding negatively. Scotch broom's recovery according to its original abundance ranking among debris treatments also could be attributed to legacy effects of the species on soil chemical properties that favor its recruitment and growth over other species (Grove et al., 2012, 2017)

With IVC at Matlock, average size and stand volume of Douglas-fir were ranked among logging-debris treatments as piled $>$ dispersed $>$ removed (Table 3). This superior growth response in the piled treatment can be attributed partially to lower covers of Scotch broom (22\%), trailing blackberry $(46 \%)$ and salal $(25 \%)$ relative to their abundances where debris was dispersed or removed (Fig. 3). Another cause for the superior growth response is from neighborhood effects of debris piles, which facilitated greater survival of Douglas-fir (discussed below).

The intercept coefficient for AVC in the regression of Douglas-fir cover versus Scotch broom cover indicated that Douglas-fir cover after AVC averaged 16\% greater than after IVC, regardless of Scotch broom cover (Fig. 6). This difference in Douglas-fir cover can be attributed directly to the $16 \%$ difference in Douglas-fir survival between AVC (74.6\%) and IVC (58.5\%). The absence of additional treatment effects on the cover regressions suggests that competitive interactions are driving species' abundances rather than direct effects of the loggingdebris and vegetation-control treatments. A cover of trailing blackberry $>40 \%$ is predicted to result in $30 \%$ or less cover of Scotch broom. Where survival of Douglas-fir is adequate at Matlock, ultimately it will likely dominate over and suppress Scotch broom and trailing blackberry.

\subsection{Douglas-fir tree and stand characteristics}

Douglas-fir stand responses that have occurred in the last five years of this study continue to be primarily attributable to treatment effects on competitive relationships among the dominant species. With the onset of crown closure, we expect that effects of the overstory Douglasfir on microclimate and resource availability, and their interactions with treatment effects, to become the predominant drivers of forest productivity. Where AVC was applied at Matlock, average size and stand volume of Douglas-fir did not differ among logging-debris treatments. Likewise, at Molalla there were no differences in the Douglas-fir variables attributable to the logging-debris treatments. This confirms that stand development and wood production continue to not differ between simulated "bole-only" (debris-dispersed) and "whole-tree" (debris-removed) harvesting, as reported previously for Matlock and Molalla (Harrington and Schoenholtz, 2010; Slesak et al., 2016) and most other sites in the North American LTSP study up to 20 years after treatment (Sanchez et al., 2006; Ponder et al., 2012; Holub et al., 2013; 

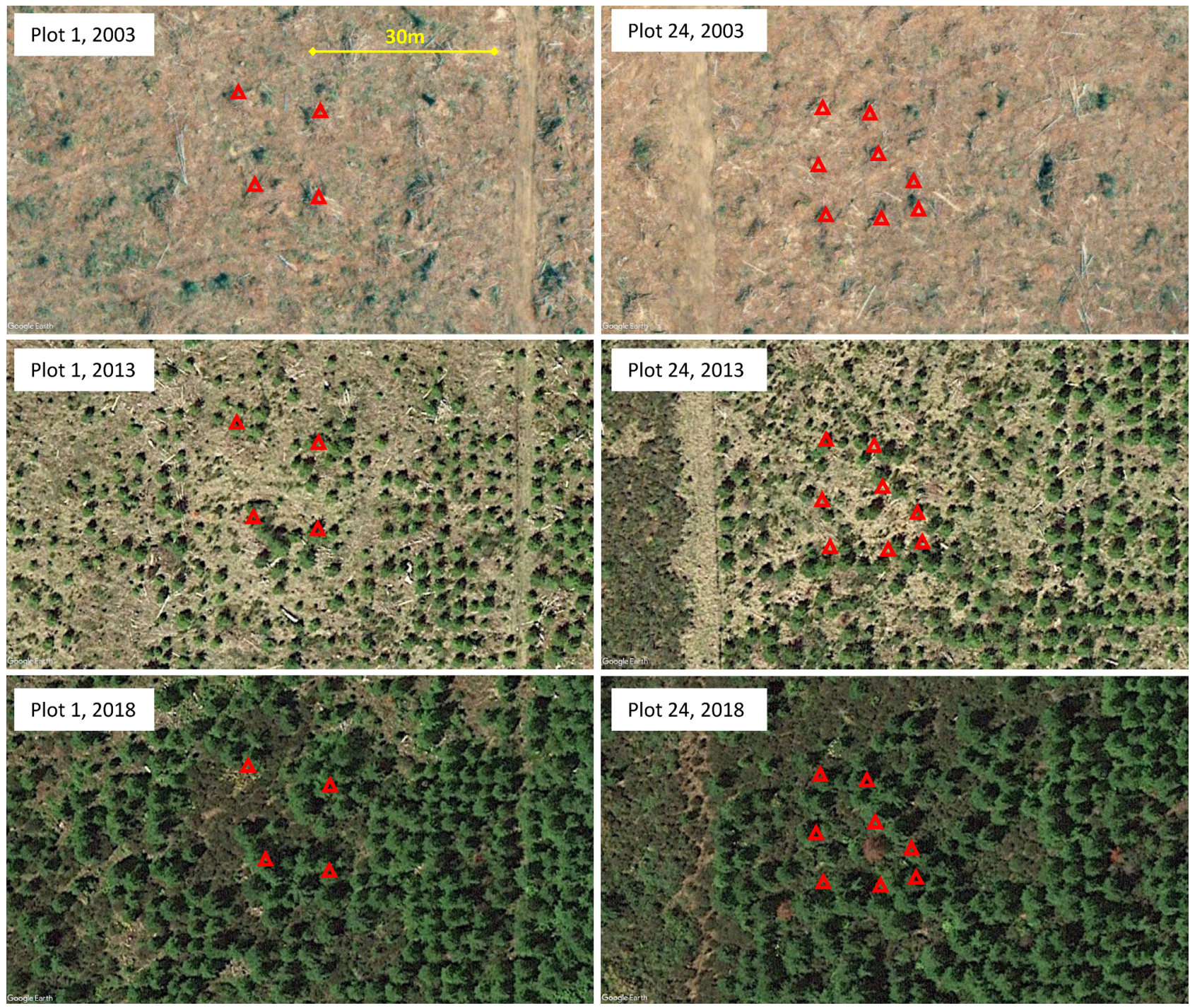

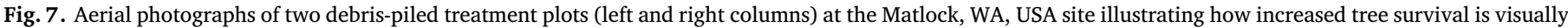

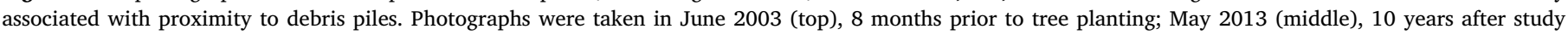

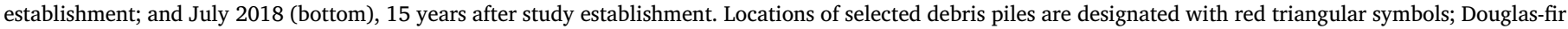

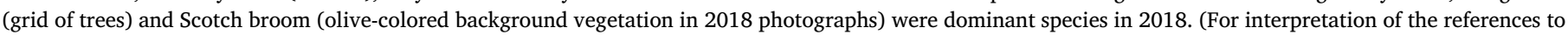
colour in this figure legend, the reader is referred to the web version of this article.)

\section{Zhang et al., 2017).}

At Matlock, vegetation control continued to show positive effects on Douglas-fir survival, average tree size, and stand volume. Survival in AVC was 16\% higher than in IVC because of tree mortality in IVC from Scotch broom competition (Harrington and Schoenholtz, 2010; Slesak et al., 2016). At Molalla, stand volume in AVC was 30\% greater than in IVC because of increased growth in height and stem diameter and not from differences in tree survival (Table 1). These increases in tree growth attributable to vegetation control have also been shown consistently for nearly all LTSP Study sites (Ponder et al., 2012), as well as for other Pacific Northwestern conifer species besides Douglas-fir (Flamenco et al., 2019).

At Matlock, the interaction of the logging-debris and vegetationcontrol treatments was significant for $\mathrm{dbh}$, height, and stand volume because these variables did not differ between AVC and IVC where debris was piled but they did where debris was dispersed or removed. During years 5 to 15 at Matlock, Douglas-fir in the debris-piled treatment with IVC increased stem growth relative to those in AVC (data not shown), eliminating differences in stem diameter between IVC and AVC (Table 2) that existed in year 5 (Harrington and Schoenholtz, 2010). In a study of radiata pine (Pinus radiata D. Don) in New Zealand, Ballard (1978) found greater growth for trees growing in or near windrows left after forest harvesting versus in non-windrowed areas. Harrington et al. (2013) observed that, in the absence of competing vegetation, Douglasfir growth, foliar $\mathrm{N}$ content, and soil water content were greater in the presence versus absence of high levels (i.e., 80\% cover) of logging debris. McCavour et al. (2014) found that soil concentrations of cations and available $\mathrm{N}$ and foliar nutrition and growth of pin cherry (Prunus pensylvanica L. f.) each decreased with distance from debris piles composed of woody matter from harvested hybrid poplar (Populus spp.) or white and black spruce (Picea glauca and P. mariana (Mill.) Britton et al., respectively). Given the above, we hypothesize that the debris piles at Matlock functioned as, both, a source of soil resources and a gap in the cover of competing vegetation. Thus, beginning in year 5 or possibly earlier, Douglas-fir located near piles in IVC-treated plots at Matlock likely were able to access additional soil water and nutrients resulting in stem growth responses that: (1) eliminated differences in dbh between IVC and AVC, and (2) were superior to IVC-treated plots in the debris-dispersed and debris-removed treatments (Table 3). Further support for this hypothesis comes from the finding that survival of 
individual Douglas-fir growing $\leq 1 \mathrm{~m}$ from the edge of debris piles averaged $16 \%$ higher than that of trees growing $>1 \mathrm{~m}$ from debris piles.

\section{Conclusions}

Consistent with previous reports from this study, results 15 years after study establishment indicate low potential for negative effects of the logging-debris and vegetation-control treatments on pools of mineral soil $\mathrm{C}$ and $\mathrm{N}$ at $0-$ to $60-\mathrm{cm}$ depth. However, the contrasting treatment responses between sites highlight the potential for site-specific factors to influence the response. These factors include inherent differences in soil chemical and physical properties and post-treatment vegetation communities. In regards to the vegetation community, the positive effects of IVC at Matlock on mineral soil C and nutrients were probably caused, in part, by the high abundance of Scotch broom in that treatment. Although these soil responses may improve long-term soil quality, the concurrent impact of Scotch broom on Douglas-fir survival and growth may offset soil benefits.

The study demonstrated how several dominant species at Matlock responded differentially to the logging-debris treatments resulting in differences in Scotch broom abundance from a secondary invasion following a control treatment in year 4 . Where debris was dispersed, higher abundances of trailing blackberry and salal restricted the secondary invasion by Scotch broom. Conversely, where debris was removed, recruitment of trailing blackberry and salal was not favored and Scotch broom recovery was unfettered. In contrast to Matlock, dominant competitors at Molalla did not respond differentially to the logging debris configurations, as determined from analyses of the 10th-year vegetation data. In addition, Douglas-fir at Molalla did not incur high levels of tree mortality from a severe competitor, such as Scotch broom; hence, forest productivity was relatively similar among the loggingdebris treatments.

Research results also indicated that, when confounding between the logging-debris and vegetation-control treatments was minimized via AVC, there were no effects on forest productivity from the loggingdebris treatments at either site. However, treatment interactions associated with IVC at Matlock caused forest productivity to be ranked among logging-debris treatments as: piled $>$ dispersed $>$ removed. This study is perhaps the first to report how logging-debris and vegetation-control treatments influence vegetation recruitment and competitive relationships among dominant plant species to impact longerterm forest productivity.

\section{Declaration of Competing Interest}

The authors declare that they have no known competing financial interests or personal relationships that could have appeared to influence the work reported in this paper.

\section{Acknowledgements}

Financial support for this research was provided by the USDA National Institute for Food and Agriculture (Grants.gov number: GRANT11325729) and the USDA Forest Service, Pacific Northwest Research Station. The authors are especially grateful to Randall Greggs, Green Diamond Resource Company, and Mike Warjone, Port Blakely Tree Farms LLC, for providing critical logistical and financial support that made this study possible. Thanks also to the helpful comments from the Associate Editor, two anonymous reviewers, and Kim Littke, University of Washington.

\section{Appendix A. Supplementary material}

Supplementary data to this article can be found online at https:// doi.org/10.1016/j.foreco.2020.118288.

\section{References}

Ballard, R., 1978. Effect of slash and soil removal on the productivity of second rotation radiata pine on a pumice soil. N. Z. J. For. Sci. 8 (2), 248-258.

Broadbent, A.A.D., Orwin, K.H., Peltzer, D.A., Dickie, I.A., Mason, N.W.H., Ostle, N.J. Stevens, C.J., 2017. Invasive N-fixer impacts on litter decomposition driven by changes to soil properties not litter quality. Ecosystems 20, 1151-1163.

Brown, J.K., 1974. Handbook for inventorying downed woody material. USDA For. Serv. Gen. Tech. Rep, INT-16.

Bruce, D., DeMars, D.J., 1974. Volume equations for second-growth Douglas-fir. USDA Forest Service, Pacific Northwest Forest and Range Experiment Station, Portland, OR. Research Note PNW-239.

Caldwell, B.A., 2006. Effects of invasive scotch broom on soil properties in a Pacific coastal prairie soil. Appl. Soil Ecol. 32, 149-152.

Cox, S.K., Van Lear, D.H., 1985. Biomass and nutrient accretion on Piedmont sites following clearcutting and natural regeneration of loblolly pine. In: Shoulders, E. (ed.), Proc. Third Biennial South. Silv. Res. Conf. USDA Forest Serv. Gen. Tech. Rep. SO-54, pp. 501-506.

Devine, W.D., Harrington, C.A., 2007. Influence of harvest residues and vegetation on microsite soil and air temperatures in a young conifer plantation. Agric. For. Meteorol. 145, 125-138.

Devine, W.D., Harrington, T.B., Terry, T.A., Harrison, R.B., Slesak, R.A., Peter, D.H., Harrington, C.A., Shilling, C.J., Schoenholtz, S.H., 2011. Five-year vegetation control effects on aboveground biomass and nitrogen content and allocation in Douglas-fir plantations on three contrasting sites. For. Ecol. Manage. 262, 2187-2198.

Dinger, E.J., Rose, R., 2009. Integration of soil moisture, xylem water potential, and fall spring herbicide treatments to achieve the maximum growth response in newly planted Douglas-fir seedlings. Can. J. For. Res. 39, 1401-1414.

Flamenco, H.N., Gonzalez-Benecke, C.A., Wightman, M.G., 2019. Long-term effects of vegetation management on biomass stock of four coniferous species in the Pacific Northwest United States. For. Ecol. Manage. 432, 276-285.

Fleming, R.L., Powers, R.F., Foster, N.W., Kranabetter, J.M., Scott, D.A., Felix Ponder, J., Berch, S., Chapman, W.K., Kabzems, R.D., Ludovici, K.H., Morris, D.M., PageDumroese, D.S., Sanborn, P.T., Sanchez, F.G., Stone, D.M., Tiarks, A.E., 2006. Effects of organic matter removal, soil compaction, and vegetation control on 5-year seedling performance: a regional comparison of Long-Term Soil Productivity sites. Can. J. For. Res. 36, 529-550.

Grier, C.C., Lee, K.M., Nadkarni, N.M., Klock, G.0., Edgenon, P.J., 1989. Productivity of forests of the United States and its relation to soil and site factors and management practices: a review. USDA For. Serv. Gen. Tech. Rep. PNW-GTR-222.

Grove, S., Haubensak, K.A., Parker, I.M., 2012. Direct and indirect effects of allelopathy in the soil legacy of an exotic plant invasion. Plant Ecol. 213, 1869-1882.

Grove, S., Parker, I.M., Haubensak, K.A., 2017. Do impacts of an invasive nitrogen-fixing shrub on Douglas-fir and its ectomycorrhizal mutualism change over time following invasion? J. Ecol. 105, 1687-1697.

Halverson, N.M., Topik, C., Van Vickle, R., 1986. Plant association and management guide for the western hemlock zone. Mount Hood National Forest, USDA Forest Service, Pacific Northwest Region. R6-ECOL-232A-1986. Portland, Oregon. pp. 62-65.

Harrington, T.B., Schoenholtz, S.H., 2010. Effects of logging-debris treatments on fiveyear development of competing vegetation and planted Douglas-fir. Can. J. For. Res. 40, 500-510.

Harrington, T.B., Slesak, R.A., Schoenholtz, S.H., 2013. Variation in logging debris cover influences competitor abundance, resource availability, and early growth of planted Douglas-fir. For. Ecol. Manage. 296, 41-52.

Harrington, T.B., Peter, D.H., Slesak, R.A., 2018. Logging debris and herbicide treatments improve growing conditions for planted Douglas-fir on a droughty forest site invaded by Scotch broom. For. Ecol. Manage. 417, 31-39.

Haubensak, K.A., Parker, I.M., 2004. Soil changes accompanying invasion of the exotic shrub Cytisus scoparius in glacial outwash prairies of western Washington [USA]. Plant Ecol. 175, 71-79.

Henderson, J.A., Peter, D.H., Lesher, R.D., Shaw, D.C., 1989. Forested plant associations of the Olympic National Forest. R6-ECOL-TP 001-88, U. S. Dept. of Agriculture, Forest Service, Pacific Northwest Region, Portland, OR.

Hendrickson, O.A., 1988. Biomass and nutrients in regenerating woody vegetation following whole-tree and conventional harvest in a northern mixed forest. Can. J. For. Res. 18, 1427-1436.

Holub, S.M., Terry, T.A., Harrington, C.A., Harrison, R.B., Meade, R., 2013. Tree growth ten years after residual biomass removal, soil compaction, tillage, and competing vegetation control in a highly-productive Douglas-fir plantation. For. Ecol. Manage. $305,60-66$.

King, J.E., 1966. Site index curves for Douglas-fir in the Pacific Northwest. Weyerhaeuser Forestry Paper No. 8. Weyerhaeuser Company, Forestry Research Center, Centralia, WA.

Littke, K.M., Harrington, T.B., Slesak, R.A., Holub, S.M., Hatten, J.A., Gallo, A.C., Littke, W.R., Harrison, R.B., Turnblom, E.C., 2020. Impacts of organic matter removal and vegetation control on nutrition and growth of Douglas-fir at three Pacific Northwestern Long-Term Soil Productivity sites. For. Ecol. Manage. https://doi.org/ 10.1016/j.foreco.2020.118176.

Maguire, D.A., Mainwaring, D.B., Rose, R., Garber, S.M., Dinger, E.J., 2009. Response of coastal Douglas-fir and competing vegetation to repeated and delayed weed control treatments during early plantation development. Can. J. For. Res. 39, 1208-1219.

McCavour, M.J., Paré, D., Messier, C., Thiffault, N., Thiffault, E., 2014. The role of 
aggregated forest harvest residue in soil fertility, plant growth, and pollination services. Soil Sci. Soc. Am. J. 78, 196-207.

Neter, J., Wasserman, W., Kutner, M.H., 1989. Applied Linear Regression Models, second ed. Richard D. Irwin Inc, Homewood, IL, pp. 271-284.

O'Connell, A.M., Grove, T.S., Mendham, D.S., Rance, S.J., 2004. Impact of harvest residue management on soil nitrogen dynamics in Eucalyptus globulus plantations in south western Australia. Soil Biol. Biochem. 36, 39-48.

Peter, D.H., Harrington, T.B., 2018. Effects of forest harvesting, logging debris, and herbicides on the composition, diversity and assembly of a western Washington, USA plant community. For. Ecol. Manage. 417, 18-30.

Ponder Jr., F., Fleming, R.L., Berch, S., Busse, M.D., Elioff, J.D., Hazlett, P.W., Kabzems, R.D., Kranabetter, J.M., Morris, D.M., Page-Dumroese, D., Palik, B.J., Powers, R.F., Sanchez, F.G., Scott, D.A., Stagg, R.H., Stone, D.M., Young, D.H., Zhang, J., Ludovici, K.H., McKenney, D.W., Mossa, D.S., Sanborn, P.T., Voldseth, R.A., 2012. Effects of organic matter removal, soil compaction and vegetation control on $10^{\text {th }}$ year biomass and foliar nutrition: LTSP continent-wide comparisons. For. Ecol. Manage. 278, 35-54.

Powers, R.F., Alban, D.H., Ruark, G.A., Tiarks, A.E., Goudey, C.B., Ragus, J.F., Russell, W.E., 1989. Study plan for evaluating timber management impacts on long-term site productivity: a research and national forest system cooperative study. Unpublished study on file with the USDA Forest Service, Washington, DC.

Powers, R.F., Alban, D.H., Miller, R.E., Tiarks, A.E., Wells, C.G., Avers, P.E., Cline, R.G., Fitzgerald, R.O., Loftus Jr., N.S., 1990. Sustaining site productivity in North American forests: problems and prospects. In: Gessel, S.P. et al. (Eds.), Sustained Productivity of Forest Soils. Forestry Publications, University of British Columbia, Vancouver, B.C., pp. 49-80.

Powers, R.F., Ferrell, G.T., 1996. Moisture, nutrient, and insect constraints on plantation growth: the "Garden of Eden" study. N. Z. J. For. Sci. 26 (1/2), 126-144.

Powers, R.F., Fiddler, G.O., 1997. The North American Long-Term Soil Productivity Study: progress through the first 5 years. Proc. Eighteenth Ann. For. Veg. Mgt. Conf. 88-102.

Powers, R.F., Scott, D.A., Sanchez, F.G., Voldseth, R.A., Page-Dumroese, D., Elioff, J.D., Stone, D.M., 2005. The North American long-term soil productivity experiment: findings from the first decade of research. For. Ecol. Manage. 220, 31-50.

PRISM Climate Group, 2019. Oregon State University, http://prism.oregonstate.edu
Accessed [7/19/2019].

Roberts, S.D., Harrington, C.A., Terry, T.A., 2005. Harvest residue and competing vegetation affect soil moisture, soil temperature, $\mathrm{N}$ availability, and Douglas-fir seedling growth. Forest Ecol. Manage. 205, 333-350.

Sanchez, F.G., Scott, D.A., Ludovici, K.H., 2006. Negligible effects of severe organic matter removal and soil compaction on loblolly pine growth over 10 years. For. Ecol. Manage. 227, 145-154.

SAS Institute, Inc., 2013. The SAS System for Windows, Version 9.4. Cary, North Carolina.

Slesak, R.A., Schoenholtz, S.H., Harrington, T.B., Strahm, B.D., 2009. Dissolved carbon and nitrogen leaching following variable logging-debris retention and competingvegetation control in Douglas-fir plantations of western Oregon and Washington. Can. J. For. Res. 39, 1484-1497.

Slesak, R.A., Schoenholtz, S.H., Harrington, T.B., 2011. Soil carbon and nutrient pools in Douglas-fir plantations 5 years after manipulating biomass and competing vegetation in the Pacific Northwest. For. Ecol. Manage. 262, 1722-1728.

Slesak, R.A., Harrington, T.B., Peter, D.H., DeBruler, D.G., Schoenholtz, S.H., Strahm, B.D., 2016. Effects of intensive management practices on 10-year Douglas-fir growth, soil nutrient pools, and vegetation communities in the Pacific Northwest. USA. For. Ecol. Manage. 365, 22-33.

Soil Survey Staff, Natural Resources Conservation Service, United States Department of Agriculture, 2019. Official Soil Series Descriptions. https://soilseries.sc.egov.usda. gov/osdname.aspx Accessed [7/22/2019].

Sokal, R.R., Rohlf, F.J., 1981. In: Biometry, second ed., W. H. Freeman and Co., San Francisco, CA. pp. 245, 419-421, 427-428.

Thiffault, E., Hannam, K.D., Paré, D., Titus, B.D., Hazlett, P.W., Maynard, D.G., Brais, S., 2011. Effects of forest biomass harvesting on soil productivity in boreal and temperate forests - A review. Environ. Rev. 19, 278-309.

Trottier-Picard, A., Thiffault, E., DesRochers, A., Paré, D., Thiffault, N., Messier, C., 2014 Amounts of logging residues affect planting microsites: A manipulative study across northern forest ecosystems. For. Ecol. Manage. 312, 203-215.

Zhang, J., Busse, M.D., Young, D.H., Fiddler, G.O., Sherlock, J.W., Tenpas, J.D., 2017 Aboveground biomass responses to organic matter removal, soil compaction, and competing vegetation control on 20-year mixed conifer plantations in California. For. Ecol. Manage. 401, 341-353. 